\title{
Removal of deltamethrin insecticide over highly porous activated carbon prepared from pistachio nutshells
}

\author{
A. F. Hassan ${ }^{1,}$, A. M. Youssef ${ }^{2}$ and P. Priecel $^{3}$ \\ ${ }^{1}$ Chemistry Department, Faculty of Science, Damanhour University, El-Gomhoria Street, 22511 Damanhour, Egypt \\ ${ }^{2}$ Chemistry Department, Faculty of Science, Mansoura University, El-Gomhoria Street, 35516 Mansoura, Egypt \\ ${ }^{3}$ Department of Physical Chemistry, Faculty of Chemical Technology, University of Pardubice, Studentska 573, 53210 Pardubice, \\ Czech Republic
}

\section{Article Info}

Received 28 July 2013

Accepted 3 September 2013

*Corresponding Author

E-mail: Asmz68@yahoo.com

\section{Open Access}

DOI: http://dx.doi.org/

10.5714/CL.2013.14.4.234

This is an Open Access article distributed under the terms of the Creative Commons Attribution Non-Commercial License (http://creativecommons.org/licenses/ by-nc/3.0/) which permits unrestricted non-commercial use, distribution, and reproduction in any medium, provided the original work is properly cited.

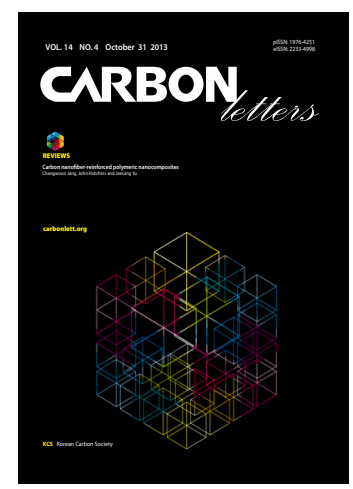

http://carbonlett.org

pISSN: 1976-4251

elSSN: 2233-4998

Copyright $\odot$ Korean Carbon Society

\begin{abstract}
Potassium hydroxide-activated carbons (CK21, CK11, and CK12) were prepared from pistachio nutshells. Physicochemical properties of activated carbons were characterized by TGA, $\mathrm{pH}_{\mathrm{pzc}}$, Fourier transform infrared spectroscopy, scanning electron microscopy, and $\mathrm{N}_{2}$-adsorption at $-196^{\circ} \mathrm{C}$. The examinations showed that activated carbons have high surface area ranging between $695-1218 \mathrm{~m}^{2} / \mathrm{g}$, total pore volume ranging between $0.527-0.772$ $\mathrm{mL} / \mathrm{g}$, and a pore radius around $1.4 \mathrm{~nm}$. The presence of acidic and basic surface $\mathrm{C}-\mathrm{O}$ groups was confirmed. Batch adsorption experiments were carried out to study the effects of adsorbent dosage, temperature, initial concentration of adsorbate, and contact time on deltamethrin adsorption by activated carbons. The kinetic studies showed that the adsorption data followed a pseudo-second order kinetic model. The Langmuir model showed a maximum adsorption capacity of $162.6 \mathrm{mg} / \mathrm{g}$ at $35^{\circ} \mathrm{C}$ on CK12. Thermodynamic studies indicated that adsorption was spontaneous and increased with temperature, suggesting an endothermic process.
\end{abstract}

Key words: activated carbon, pistachio nutshells, insecticide, deltamethrin, adsorption

\section{Introduction}

Pesticides are considered one of the most hazardous groups of pollutants in water and air due to their high stability and toxicity, usage in huge quantities, and wide applications for many purposes, particularly the production of massive quantities of crops. In general, pesticides are defined as a diverse group or mixture of chemical compounds, biological agents, antimicrobials, disinfectants or devices that are intentionally applied for selective administration and attenuation against any pests including insects, plant pathogens, weeds, birds, nematodes, and microbes that detrimentally affect the production, processing, storage, transport, or marketing of food or agricultural compounds or are responsible for the destruction of property or spread of diseases [1-3]. The herbicide component bentazone was studied via adsorption removal over activated carbon cloth as an electrode and it was found that a change of $\mathrm{pH}$ from 2 to 7 reduced the adsorption capacity from $127 \mathrm{mg} / \mathrm{g}$ to $80 \mathrm{mg} / \mathrm{g}$ [4]. Deltamethrin is a synthetic pyrethroid insecticide that kills insects on contact and through digestion. It is used for many crops throughout the year, and consequently is widespread in the environment. Furthermore, it is non-degradable during storage for 6 months at $40^{\circ} \mathrm{C}$, it is stable when exposed to atmospheric oxygen, and isomerization occurs upon exposure to sunlight. Acute effects on the human body include the following: ataxia, convulsions leading to muscle fibrillation and paralysis, diarrhea, edema, dermatitis, dyspnea, headache, irritability, hepatic microsomal enzyme induction, peripheral vascular collapse, rhinorrhea, serum alkaline phosphate elevation, tinnitus, vomiting, and death due to respiratory failure. Allergic reactions include the following manifestations: anaphylaxis, bronchospasm, eosinophil- 


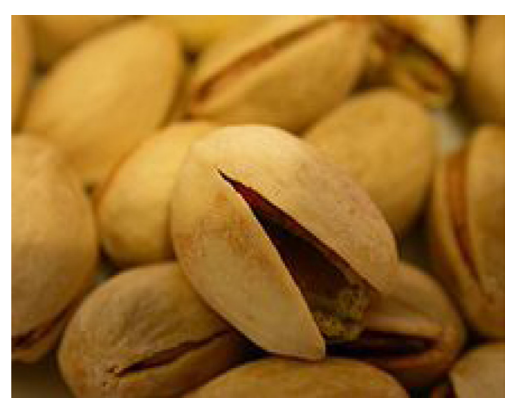

Fig. 1. Pistachio nutshells.

\begin{tabular}{|c|c|c|c|c|c|}
\hline Country & Iran & USA & Turkey & Syria & China \\
\hline $\begin{array}{l}\text { Production } \\
\text { (Mt) }\end{array}$ & $\begin{array}{l}192 \\
269\end{array}$ & $\begin{array}{l}126 \\
100\end{array}$ & $\begin{array}{l}120 \\
113\end{array}$ & 52600 & 40000 \\
\hline
\end{tabular}

ia, fever, hypersensitivity pneumonia, sweating, pallor, pollinosis, sudden swelling of the face, eyelids, lips, and mucous membranes, and tachycardia. Chronic exposure effects in humans include choreoathetosis, hypotension, prenatal damage, and shock [5].

Adsorption on a solid surface is still the most important and useful method for removal of pollutants due to their high adsorption capacity, simple recovery process from the solid surface, and simple handling. Activated carbons are still the primarily used solid adsorbents due to their chemical inertness, high surface area, microporosity, presence of surface functional groups, renewability, capacity for simple surface modification to adsorb certain contaminants, and the possibility of production from solid agricultural waste byproducts. Activated carbons have the ability to adsorb various substances both from gas and liquid phases $[6,7]$. Activated carbons are produced from a solid carbonaceous material that is rich in carbon but low in inorganic content. Pistachio nutshells (Fig. 1) are considered one of the most useful and abundant renewable agricultural wastes, as reported by the Food and Agricultural Organization of the United Nations (Table 1).

The main objective of this research is to prepare potassium hydroxide $(\mathrm{KOH})$-activated carbons from pistachio nutshells. The following methods were used to characterize the prepared activated carbons: nitrogen adsorption at $-196^{\circ} \mathrm{C}$, scanning electron microscopy, thermogravimetric analysis, Fourier transform infrared spectroscopy (FT-IR) analysis of the surface chemistry, $\mathrm{pH}_{\mathrm{pzc}}$, surface $\mathrm{pH}$ analysis, and measurement of deltamethrin adsorption capacity at different temperatures. Special attention was paid to kinetic and thermodynamic studies.

\section{Materials and Methods}

\subsection{Materials}

\subsubsection{Adsorbents}

Pistachio nutshells collected from pistachio nuts obtained from El-Mansoura City (Egypt) local markets were used as a precursor. They were washed with distilled water to remove any adherent im-

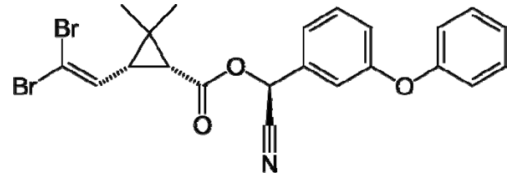

Fig. 2. Chemical structure of deltamethrin.

purities and then dried at $110^{\circ} \mathrm{C}$ for $24 \mathrm{~h}$ and then ground and sieved to yield particle size ranging from $1-2 \mathrm{~mm}$. Three activated carbon samples were prepared via a two-step method: carbonization of the dried precursor at $600^{\circ} \mathrm{C}$ in the absence of air using a stainless steel reactor $(600 \mathrm{~mm} \times 40 \mathrm{~mm})$ at a rate of $10^{\circ} \mathrm{C} / \mathrm{min}$. up to $600^{\circ} \mathrm{C}$. The carbonized sample was cooled and soaked with a certain weight of $\mathrm{KOH}$ in $50 \mathrm{~mL}$ of distilled water for $48 \mathrm{~h}$ at room temperature, followed by drying at $110^{\circ} \mathrm{C}$ and finally activated at $750^{\circ} \mathrm{C}$ for $4 \mathrm{~h}$. Three samples were prepared using different carbonized samples: $\mathrm{KOH}$ ratios. These samples were designated as CK21, CK11, and $\mathrm{CK} 12$, where the ratio of carbonized samples to $\mathrm{KOH}$ weights was $2: 1,1: 1$, and $1: 2$, respectively. Prepared samples were washed several times with distilled water and then dried at $110^{\circ} \mathrm{C}$ to reach a constant weight, and then stored in clean and dry-fitted glass bottles.

\subsubsection{Adsorbate}

Deltamethrin insecticide was provided by KZ Company for Pesticides and Chemical Industries (Kafr El-Ziat City-Egypt) in $98 \%$ purity and a molar mass of $505.21 \mathrm{~g} / \mathrm{mol}$ with a chemical structure as shown in Fig. 2. The solubility of deltamethrin in water is low, and a mixed solvent of ethanol/water $(50 \mathrm{vol} / \mathrm{vol} \%$ ratio) was therefore used to allow preparation of the required experimental concentrations.

\subsection{Techniques}

\subsubsection{Surface chemistry of samples}

To obtain a complete picture of the samples surface chemistry was determined using the following technique: FT-IR using a Mattson 5000 FT-IR spectrometer in a range between 4000 and $400 \mathrm{~cm}^{-1}$, where discs were prepared by mixing $1 \mathrm{mg}$ of dried carbon sample with $500 \mathrm{mg}$ of $\mathrm{KBr}$ (spectroscopic purity, Merck) in an agate mortar followed by pressing the mixture at 5 ton/ $\mathrm{cm}^{3}$ for $3 \mathrm{~min}$ and 10 ton $/ \mathrm{cm}^{3}$ for 5 min under vacuum. The $\mathrm{pH}$ of the supernatant was determined by shaking $0.5 \mathrm{~g}$ of the carbon sample with $25 \mathrm{~mL}$ of $\mathrm{CO}_{2}$-free distilled water for $24 \mathrm{~h}$; the $\mathrm{pH}$ of the supernatant was then measured. $\mathrm{pH}_{\mathrm{pzc}}$ (point of zero charge) was determined by adding $50 \mathrm{~mL}$ of sodium chloride into several closed flasks. The $\mathrm{pH}$ within each flask was adjusted to values ranging from 2 to 12 by adding either sodium hydroxide $(0.1 \mathrm{M})$ or hydrochloric acid $(0.1 \mathrm{M})$.Then, $0.2 \mathrm{~g}$ of carbon was added to each flask, the flasks were shaken for $48 \mathrm{~h}$, and the final $\mathrm{pH}$ was measured. The $\mathrm{pH}_{\mathrm{pzc}}$ is defined as the point where the curve of $\mathrm{pH}_{\text {final }}$ vs. $\mathrm{pH}_{\text {initial }}$ crosses the line $\mathrm{pH}_{\text {final }}=\mathrm{pH}_{\text {initial }}$ [8].

2.2.2. Thermal gravimetric analysis and weight loss during drying

Thermal gravimetric analysis (TGA) were performed to identify the thermal behavior of pistachio nutshells as a raw material and CK12 as a selected activated sample using a differential thermal analyzer (Shimadzu DTA-50, Japan). The weight loss during drying was determined for the raw material and activated sample by 
weighting $0.5 \mathrm{~g}$ of the sample and heating for $24 \mathrm{~h}$ in an oven at $110^{\circ} \mathrm{C}$ until the weight of the sample became constant.

\subsubsection{Textural characterization}

Textural characterization was performed using nitrogen adsorption at $-196^{\circ} \mathrm{C}$ to evaluate the specific surface area, pore radius, and total pore volume for the investigated activated carbon using a Quantachrome NOVA2000 gas sorption analyzer.

\subsubsection{Scanning electron microscopy}

Scanning electron micrographs (SEM) of CK12 were obtained using a JEOL 6400. Prior to the measurement, the samples were dried at $110^{\circ} \mathrm{C}$ for $4 \mathrm{~h}$. A thin layer of gold was coated on each sample for charge dissipation.

\subsection{Batch equilibrium studies}

Adsorption isotherms were obtained from solutions of deltamethrin with different initial concentrations and an equal mass of activated carbons placed in a set of Erlenmeyer flasks (100 $\mathrm{mL})$ at two different temperatures $\left(19^{\circ} \mathrm{C}\right.$ and $\left.35^{\circ} \mathrm{C}\right)$ that were placed in an isothermal shaker $\left(19^{\circ} \mathrm{C}\right.$ or $\left.35^{\circ} \mathrm{C}\right)$ for $24 \mathrm{~h}$ to reach equilibrium as a solid-solution mixture. The flasks were then removed from the shaker and the final concentration of deltamethrin in the supernatant was measured at $282 \mathrm{~nm}$ using a UV-vis spectrophotometer Unicam UV/VIS 5625. The adsorbed amount $\mathrm{q}_{\mathrm{e}}(\mathrm{mg} / \mathrm{g})$ was calculated as follows:

$$
q_{e}=\frac{\left(C_{o}-C_{e}\right)}{W},
$$

where $\mathrm{C}_{\mathrm{o}}$ and $\mathrm{C}_{\mathrm{e}}(\mathrm{mg} / \mathrm{L})$ are the concentrations of deltamethrin at the beginning and at equilibrium, respectively, $\mathrm{V}$ is the volume of solution (L), and $\mathrm{W}$ is the mass $(\mathrm{g})$ of dry activated carbons.

\subsection{Effects of dosage}

Effects of dosage were checked in a set of Erlenmeyer's flasks containing the same volume and the same concentrations of deltamethrin and mixed with different weights of activated carbons, shaken at a specified temperature for $24 \mathrm{~h}$ until equilibrium was reached. After this procedure the residual concentration of deltamethrin was determined.

\subsection{Batch kinetic studies}

The kinetic study procedures were identical to those of the equilibrium experiments. The solutions of the samples were taken at present time intervals, and the concentrations of insecticide were similarly measured.

\section{Results and Discussion}

\subsection{Characterization of precursor and activated carbons}

3.1.1. Solid density, drying weight loss, ash content, and thermogravimetry

Impregnation of a carbonized (non-activated carbons) sample

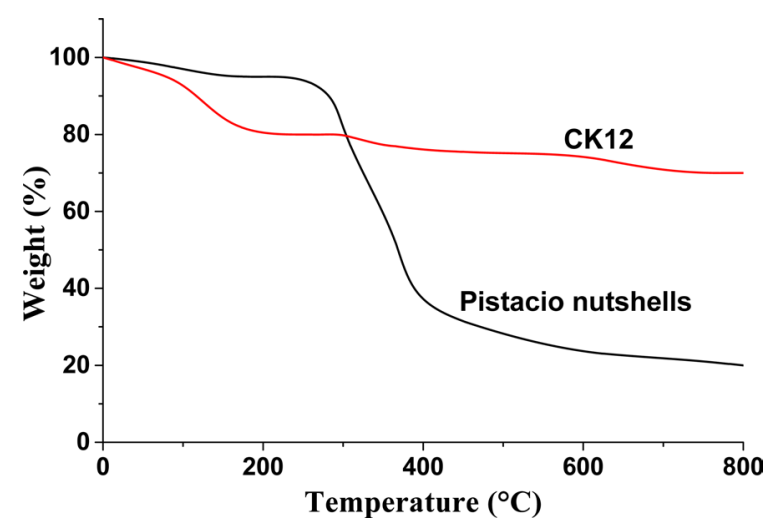

Fig. 3. TGA profile of pistachio nutshells and CK12 activated carbon.

in a concentrated $\mathrm{KOH}$ solution for a long time was followed by drying and activation at $750^{\circ} \mathrm{C}$. Drastic changes in the texture and porous surface development were anticipated when $\mathrm{KOH}$ reacted with carbon atoms, which results in a loss of carbon content and an increase in the percent of ash content according to the following equation:

$$
4 \mathrm{KOH}+\mathrm{C} \rightarrow \mathrm{K}_{2} \mathrm{O}+\mathrm{K}_{2} \mathrm{CO}_{3}+2 \mathrm{H}_{2}
$$

Some reactions may take place due to decomposition of $\mathrm{KOH}$, as listed below:

$$
\begin{aligned}
& 2 \mathrm{KOH} \rightarrow \mathrm{K}_{2} \mathrm{O}+\mathrm{H}_{2} \mathrm{O} \\
& \mathrm{C}+\mathrm{H}_{2} \mathrm{O} \rightarrow \mathrm{H}_{2}+\mathrm{CO} \\
& \mathrm{CO}+\mathrm{H}_{2} \mathrm{O} \rightarrow \mathrm{H}_{2}+\mathrm{CO}_{2} \\
& \mathrm{~K}_{2} \mathrm{O}+\mathrm{CO}_{2} \rightarrow \mathrm{K}_{2} \mathrm{CO}_{3} \\
& \mathrm{~K}_{2} \mathrm{O}+\mathrm{H}_{2} \rightarrow 2 \mathrm{~K}+\mathrm{H}_{2} \mathrm{O} \\
& \mathrm{K}_{2} \mathrm{O}+\mathrm{C} \rightarrow 2 \mathrm{~K}+\mathrm{CO} \\
& \mathrm{K}_{2} \mathrm{CO}_{3}+2 \mathrm{C} \rightarrow 2 \mathrm{~K}+3 \mathrm{CO}
\end{aligned}
$$

It was reported that the decomposition of $\mathrm{KOH}$, the reduction of the carbon framework, the evolution of hydrogen in reaction Eq. (2), and the evolution of carbon dioxide and steam as oxidizing gases in other reactions could be responsible for the production of new pores and could also lead to the erosion of pore walls [9]. Table 2 indicates that 1 ) the solid density for pistachio nutshells is lower than the solid density of activated samples and increases with an increase in ratio of $\mathrm{KOH}$ to carbonized sample; 2) weight loss during drying increases with the activation by $\mathrm{KOH}$, where weight loss during drying for CK12 is about 3.8 times higher than that of pistachio nutshells. This is a logical result of the higher surface area and production of carbon-oxygen functional groups on the activated samples, which enhance the surface adsorption of water molecules; 3 ) ash content for pistachio nutshells is very low $(1.01 \%)$ due to the higher amount of cellulose and lignin [10]; and 4) during activation, $\mathrm{KOH}$ reduces the carbon content in the samples followed by an increase in ash content, which intensifies with an increase of the $\mathrm{KOH}$ ratio.

The shape of the TGA profile depends on the thermal behavior of the biomass, which is related to the chemical composition and chemical bonding in the material structure. TGA provide provides an indication of the carbon content in the precursor and can serve as primary data for the production of activated carbon. Fig. 3 shows 
Table 2. Solid density, weight loss upon drying, ash content, $\mathrm{pH}$ of supernatant, and $\mathrm{pH}_{\mathrm{pzc}}$ for precursor and investigated samples

\begin{tabular}{cccccc} 
Sample & Solid density $\left(\mathrm{g} / \mathrm{cm}^{3}\right)$ & Weight loss on drying (\%) & Ash content (\%) & $\mathrm{pH}($ supernatant) & $\mathrm{pH}$ pzc \\
\hline Pistachio nutshells & 1.30 & 2.90 & 1.01 & 6.50 & 6.40 \\
CK21 & 1.50 & 6.51 & 3.20 & 7.70 & 7.50 \\
CK11 & 1.61 & 8.62 & 4.51 & 7.81 & 7.61 \\
CK12 & 1.68 & 10.80 & 5.81 & 8.00 & 7.80 \\
\hline
\end{tabular}
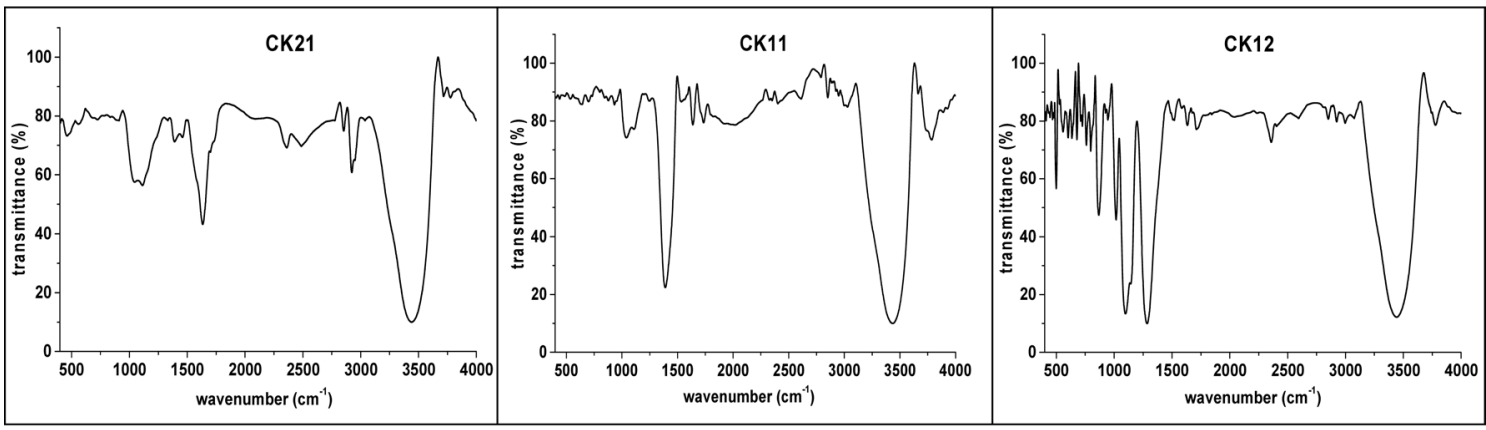

Fig. 4. FTIR spectra of the investigated activated carbons.

the effect of temperature on the residual weight of the raw pistachio nutshells and CK12 as a selected activated carbon sample. The TGA profile of pistachio nutshells shows that weight loss under $150^{\circ} \mathrm{C}$ corresponds to moisture content in the pistachio nutshells and was found to be around $3 \mathrm{wt} \%$. Carbonization reactions started to dominate beyond $150^{\circ} \mathrm{C}$. It is known that degradation of hemicelluloses starts at $200-260^{\circ} \mathrm{C}$ and cellulose degradation occurs at around $240-350^{\circ} \mathrm{C}$. Lignin is more stable than cellulose and hemicelluloses, and decomposes at a temperature range of $280-800^{\circ} \mathrm{C}$ [11]. The minor extractives of inorganic constituents and their catalytic effects also influence the weight loss of biomass during pyrolysis [12]. Significant weight loss was observed between $275^{\circ} \mathrm{C}$ and $520^{\circ} \mathrm{C}$, and is due to decomposition of the main components of the pistachio nutshells and removal of the gaseous volatile matter from the structure. At $\sim 750^{\circ} \mathrm{C}$ degradation of the lignocellulosic structure was nearly completed. Carbonization at $600^{\circ} \mathrm{C}$ was selected to obtain carbonized samples from pistachio nutshells. The activated carbon sample (CK12) was not strongly affected by temperature, where the decrease in weight under $150^{\circ} \mathrm{C}$ may be related to the removal of adsorbed moisture. This effect was more pronounced in CK12 than in pistachio nutshells due to the higher surface area of the former and the presence of hydrophilic C-O functional groups, which enhance moisture adsorption onto CK12.

\subsection{2. $\mathrm{pH}$ of supernatant, $\mathrm{pH}_{\mathrm{pzc}}$, and FT-IR}

Surface chemistry of a solid adsorbent is a very important factor in the determination of the adsorption capacity and selectivity and in identifying the chemical nature of the activated carbon surface. The values of the supernatant $\mathrm{pH}$ and the values of $\mathrm{pH}_{\mathrm{pzc}}$ are summarized in Table 2. The supernatant $\mathrm{pH}$ and $\mathrm{pH}_{\mathrm{pzc}}$ of the precursor are comparable. The supernatant $\mathrm{pH}$ and $\mathrm{pH}_{\mathrm{pzc}}$ of the $\mathrm{KOH}$-activated carbons are also comparable and increase with an increase of the amount of $\mathrm{KOH}$ used during activation.
FT-IR is mainly used as a qualitative technique for the study of surface chemical functional groups on activated carbons. Carbons are black solid materials that absorb almost all radiation in a range of 360-800 $\mathrm{nm}$ and the peaks obtained in FT-IR are commonly a sum of the interactions of the different types of surface groups [13]. Fig. 4 shows the FT-IR spectra of $\mathrm{KOH}-$ activated samples. The bands located at around $3500 \mathrm{~cm}^{-1}$ can be assigned to the $-\mathrm{OH}$ stretching vibration mode of hydroxyl functional groups [14]. The peak at around $2929 \mathrm{~cm}^{-1}$, which is easily observed in the case of CK21, indicates the presence of a methylene group (-CH2-) with $\mathrm{CH}$ stretching [15]. The peak at around $1745 \mathrm{~cm}^{-1}$ with observable transmittance in the case of CK21 and almost absent in the cases of CK11 and CK12 is attributed to lactone groups. The bands located at around 1380 and $1465 \mathrm{~cm}^{-1}$ are due to $\delta(\mathrm{C}-\mathrm{H})$ vibrational bands for $-\mathrm{CH}_{3}$ and $-\mathrm{CH} 2$ groups, respectively. Bands in the range of $1000-1300 \mathrm{~cm}^{-1}$ can be attributed to vibrations of various $\mathrm{C}-\mathrm{O}$ bonds, such as those in ethers, phenols, and esters [16,17]. The bands in the region of $850-440 \mathrm{~cm}^{-1}$ are ascribed to alkenes vibrations. Generally, the surface oxides on carbon can exhibit acidic as well as basic properties. The acidic surface properties are caused by the presence of carboxyl groups, lactones or lactols (Fig. 5a), and hydroxyl groups of a phenolic character [18]. Basic groups are usually structures corresponding to chromene- or pyrone-like structures [19] (Fig. 5b).

\subsubsection{Textural characterization of activated carbons}

Adsorption efficiency of activated carbon depends mainly on its porous structures and its surface functional groups. Many experiments have been established to determine specific surface area, total pore volume, pore radius or pore size distribution. A nitrogen adsorption process at $-196^{\circ} \mathrm{C}$ is still the primary method in textural characterization of porous materials, especially activated carbons. Fig. 6 shows the adsorption isotherms for CK21, CK11, and CK12, which are type I in their initial stage but show 
<smiles>CC(C)C1C(=O)OC(=O)C(C(C)C)C1C</smiles>

(i)carboxylic anhydride<smiles>[2H]C1C=COC(C)=C1C</smiles>

(iV)chromene<smiles>CC(C)C1OC(=O)C(C(C)C)C1C</smiles>

(ii)lactone

(A)<smiles>[R]C1C=CC(C)=C(C)O1</smiles>

(B)<smiles>CC(C)C1C(=O)OC(O)(C(C)C)C1C</smiles>

(iii)lactol<smiles>Cc1oc(C)c(C)c(=O)c1C</smiles>

(V)pyrone-like

Fig. 5. Acidic surface groups (A) and basic surface groups (B).
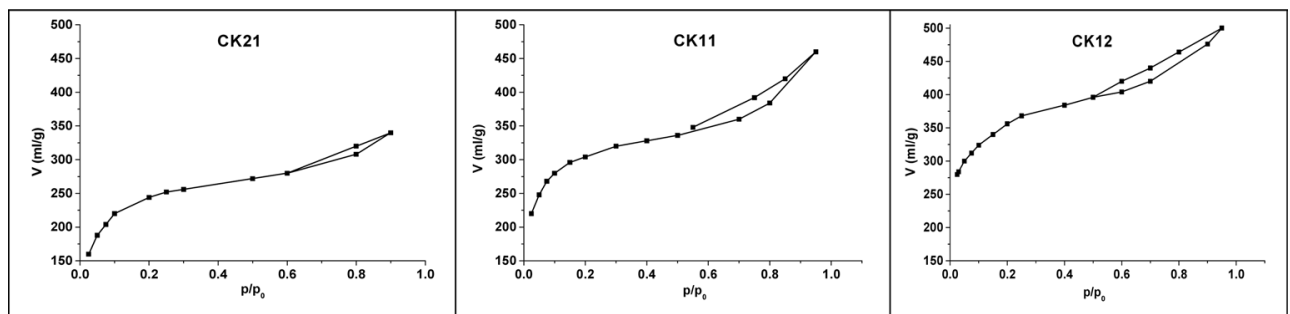

Fig. 6. Nitrogen adsorption isotherms at $-196^{\circ} \mathrm{C}$ for the investigated activated carbons.

some characteristics of type IV in later stages. The observation of a hysteresis loop indicates the presence of wider pores, which may be related to the corrosive effect of $\mathrm{KOH}$ on the microporous carbon walls. The values of surface area $\left(\mathrm{m}^{2} / \mathrm{g}\right)$, total pore volume $(\mathrm{mL} / \mathrm{g})$, and pore radius $(\mathrm{nm})$ are summarized in Table 3. The linear Brunauer-Emmett-Teller (BET) plots enabled us to determine the surface area for different activated samples $\left(\mathrm{S}_{\mathrm{BET}}\right.$ $\left.\left[\mathrm{m}^{2} / \mathrm{g}\right]\right)$ and therefore to calculate the mean pore radius $\mathrm{r}^{-}(\mathrm{nm})$ according to the following equation:

$$
r^{-}(n m)=\frac{2 V_{T}(m L / g)}{S_{B E T}\left(m^{2} / g\right)} \times 10^{3}
$$

where $\mathrm{V}_{\mathrm{T}}$ is the adsorbed volume near the saturation point, i.e.at $\mathrm{p} / \mathrm{p}^{\mathrm{o}} \approx 0.95$, multiplied by the factor $15.5 \times 10^{-4}$. Table 3 reveals that 1) the specific surface areas for the $\mathrm{KOH}$-activated samples increase in the order $695<956<1218 \mathrm{~m}^{2} / \mathrm{g}$ with change in the ratio of weight of the carbonized sample to $\mathrm{KOH}$ weight in the order 2:1<1:1<1:2, respectively, indicating that as the amount of potassium hydroxide activating agent increases the porosity and surface area also increase, but that the increase is not linear; 2) total pore volumes range between $0.527-0.772 \mathrm{~mL} / \mathrm{g}$, and increase with the amount of $\mathrm{KOH}$, and it is not surprising that the effect of the activating agent is based mainly on the creation of new pores; and 3) pore radius measurements indicate a surface containing micropores that decrease in the order $1.520>1.48>$ $1.27 \mathrm{~nm}$ for CK21, CK11, and CK12, respectively, thus demonstrating the capability of potassium hydroxide to create new pores rather than to widen existing pores.
Table 3. BET-Surface area, total pore volume, and pore radius for activated carbon samples

\begin{tabular}{cccc} 
Sample & $\mathrm{S}_{\mathrm{BET}}\left(\mathrm{m}^{2} / \mathrm{g}\right)$ & $\mathrm{V}_{\mathrm{T}}(\mathrm{mL} / \mathrm{g})$ & $\mathrm{r}^{\circ}(\mathrm{nm})$ \\
\hline $\mathrm{CK} 21$ & 695 & 0.527 & 1.52 \\
$\mathrm{CK} 11$ & 956 & 0.708 & 1.48 \\
$\mathrm{CK} 12$ & 1218 & 0.772 & 1.27 \\
\hline
\end{tabular}

BET: Brunauer-Emmett-Teller.

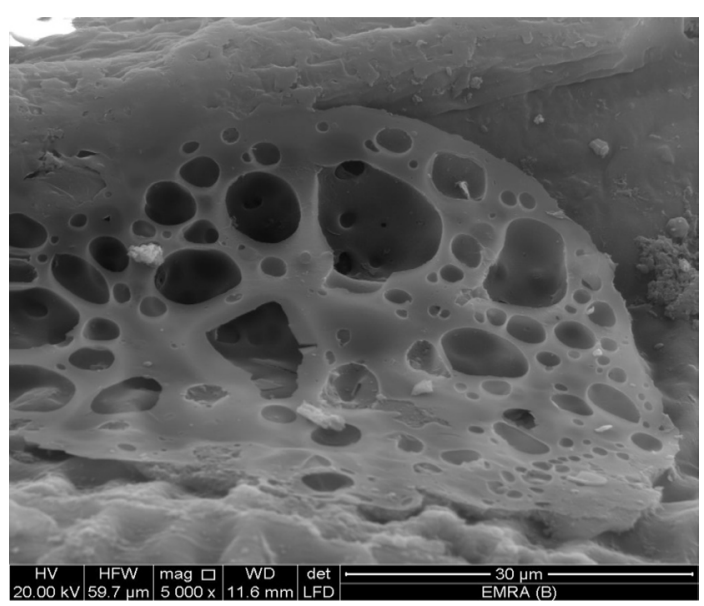

Fig. 7. SEM image of CK12 sample. 
The SEM micrograph obtained at a magnification of 5000× clearly indicates the porous structure of the activated carbons (Fig. 7). It shows that $\mathrm{KOH}$-activated carbons exhibit a wide range of pore radiuses and lack a definite morphology, possibly due to carbonization at $600^{\circ} \mathrm{C}$ and activation with $\mathrm{KOH}$ at $750^{\circ} \mathrm{C}$.

\subsection{Adsorption of deltamethrin}

\subsubsection{Effect of adsorbent dosage}

An experiment was carried out to study the effect of adsorbent dosage on deltamethrin adsorption. Various quantities of CK12, selected as an activated carbon sample, were contacted with a fixed initial pesticide concentration. Uptake of pesticide after a contact time of $24 \mathrm{~h}$ versus the adsorbent dosage $(\mathrm{g} / \mathrm{L})$ is shown in Fig. 8. The results indicate that the pesticide uptake increased from 67 to $93 \%$ when the CK12 dose was increased from 0.5 to $7.5 \mathrm{~g} / \mathrm{L}$, respectively. The maximum uptake of deltamethrin was thus obtained at a higher adsorbent dosage. This is due to the greater availability of adsorption sites for the adsorbate as the adsorbent dosage is increased, thus enhancing the deltamethrin uptake [20]. Also, with increasing adsorbent loading, the quantity of deltamethrin adsorbed onto the unit weight of the adsorbent is reduced, thus causing a decrease in the $\mathrm{q}_{\mathrm{e}}(\mathrm{mg} / \mathrm{g})$ values with increasing activated carbon loading.

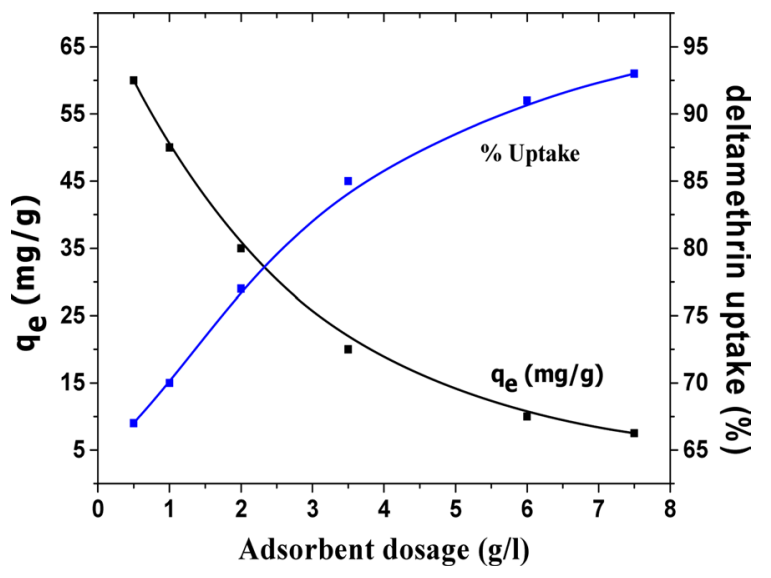

Fig. 8. Effect of adsorbent (CK12) dosage.

\subsubsection{Adsorption kinetics}

The effect of contact time was investigated to determine the equilibrium time for deltamethrin adsorption on CK21 and CK12. Fig. 9a shows an increase in deltamethrin removal for all initial concentrations of insecticide investigated. However, the adsorption was faster at the initial times but progressively slowed down with time until equilibrium was finally attained. This is attributed to the large number of vacant sites available for adsorption at the initial stages. The experimental data obtained from the adsorption of deltamethrin on CK21 and CK12 were fitted with a pseudo-second order (PSO) kinetic model but could not be fitted with a pseudo-first order kinetic model, possibly due to the dependence of the adsorption process on both the adsorption surface and deltamethrin itself. The linearized form of the PSO reaction equation can be written as:

$$
\frac{t}{q_{t}}=\frac{1}{K q_{e}^{2}}+\frac{1}{q_{e}} t
$$

where $\mathrm{K}$ is the PSO rate constant ( $\mathrm{g} / \mathrm{mg} \cdot \mathrm{min}), \mathrm{t}$ is the time in minutes, $\mathrm{q}_{\mathrm{t}}$ is the amount adsorbed in time $\mathrm{t}(\mathrm{mg} / \mathrm{g})$, and $\mathrm{q}_{\mathrm{e}}$ is the equilibrium adsorbed amount ( $\mathrm{mg} / \mathrm{g}$ ). The linearized plot for the PSO equation is shown in Fig. 9b. Table 4 contains the kinetically determined data for deltamethrin adsorption on CK21 and CK12 as selected activated samples. Upon inspection of the data shown in Table 4, we can observe that the $\mathrm{q}_{\mathrm{e}}$ values are 163 and $177 \mathrm{mg} / \mathrm{g}$ for CK21 and CK12, respectively. Column 3 of Table 4 displays the PSO rate constant, which is $1.850 \times 10^{-4}$ and $2.363 \times 10^{-4} \mathrm{~g} / \mathrm{mg}$.min for CK21 and CK12, respectively. Correlation coefficient $\left(\mathrm{R}^{2}\right)$ values are presented in Table 4, which approached unity and indicate the applicability of the PSO kinetic model for deltamethrin adsorption on $\mathrm{KOH}$-activated samples.

The intraparticle diffusion model was first proposed by Weber and Morris [21], who concluded that the uptake is proportional to the square root of the contact time during the adsorption, i.e.,

$$
\mathrm{q}_{\mathrm{t}}=\mathrm{k}_{\mathrm{d}} \mathrm{t}^{0.5}+\mathrm{C}
$$

where $k_{d}$ is the rate constant of the intraparticle transport $(\mathrm{mg} / \mathrm{g}$. $\mathrm{min}$ ). The value of $k_{d}$ was obtained from the slope of a straight line where $\mathrm{C}$ is the intercept. According to the Weber and Morris model, multilinearity may be obtained when $\mathrm{q}_{\mathrm{t}}$ is plotted versus $\mathrm{t}^{0.5}$, as shown in Fig. 10. This indicates two steps are involved in the present investigation. The first sharper line indicates the external surface adsorption. The second portion is gradual adsorption, referring to

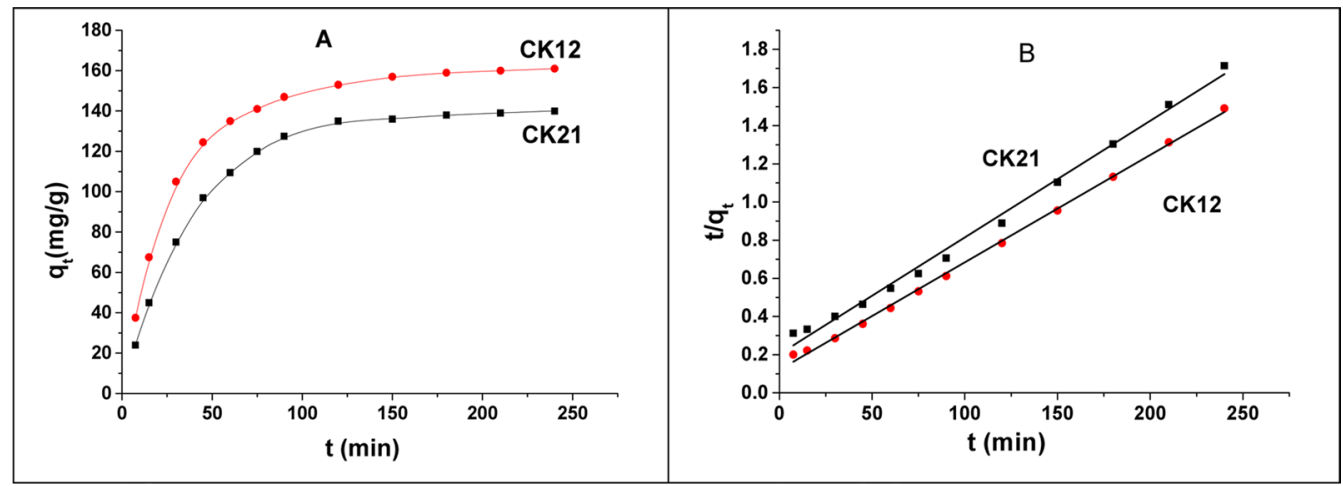

Fig. 9. Kinetic adsorption curves (A) and pseudo-second order kinetic plots (B) for adsorption of deltamethrin on CK21 and CK12. 
Table 4. Kinetic studies for adsorption of deltamethrin on CK21 and CK12

\begin{tabular}{cccccc} 
& \multicolumn{3}{c}{ PSO plot } & \multicolumn{3}{c}{ Morris-Webber plot } \\
\cline { 2 - 6 } Samples & $\mathrm{q}_{\mathrm{e}}(\mathrm{mg} / \mathrm{g})$ & $\mathrm{K}(\mathrm{g} / \mathrm{mg} \cdot \mathrm{min})$ & $\mathrm{R}^{2}$ & $\mathrm{k}$ (mg/g.min) & $\mathrm{R}^{2}$ \\
\hline CK21 & 163 & $1.850 \times 10-4$ & 0.99342 & 17.4157 & 0.99437 \\
$\mathrm{CK} 12$ & 177 & $2.363 \times 10-4$ & 0.99841 & 19.7480 & 0.96891 \\
\hline
\end{tabular}

PSO: pseudo-second order.

the intraparticle diffusion controlled adsorption process. If the lines do not pass through the origin, the intraparticle diffusion is not the rate limiting step and this indicates the effect of film diffusion on the adsorption of deltamethrin [8]. Table 4 presents the values of the constants $\mathrm{k}_{\mathrm{d}}$ and $\mathrm{C}$, as calculated by the Weber and Morris model.

\subsubsection{Equilibrium adsorption isotherms}

The adsorption isotherm indicates how the adsorbed molecules are distributed between the solid surface phase and the liquid phase when the adsorption process reaches an equilibrium state. Several adsorption models have been reported in the literature to describe the adsorption data of isotherms. The amount of deltamethrin adsorbed, $\mathrm{q}_{\mathrm{e}}(\mathrm{mg} / \mathrm{g})$, is plotted against the equilibrium concentration $\mathrm{C}_{\mathrm{e}}(\mathrm{mg} / \mathrm{L})$, as shown in Fig. 11. The isotherms have been classified according to the Giles classification into four main groups, L, S, H,

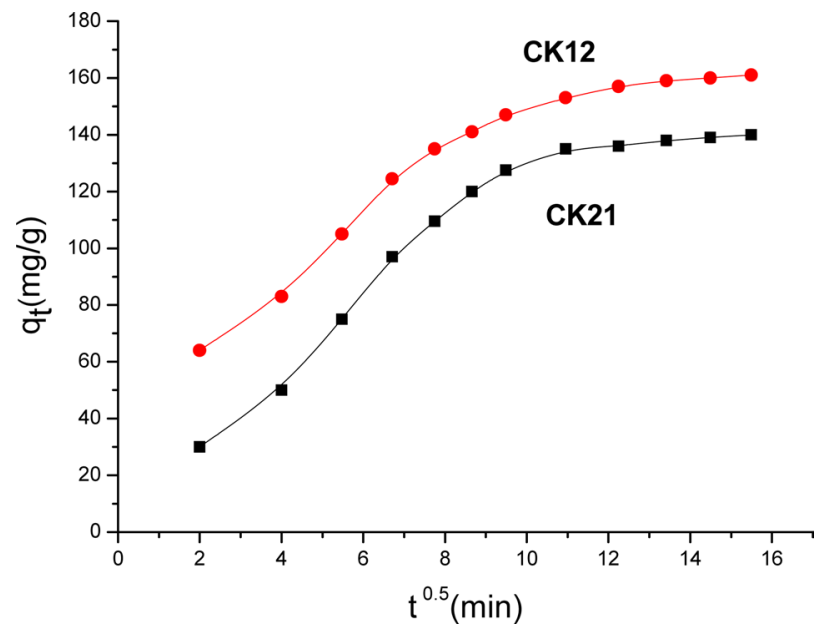

Fig. 10. Representative intraparticle diffusion plots for deltamethrin adsorption on CK21 and CK12. and $\mathrm{C}$ [22]. According to the above classification the three $\mathrm{KOH}-\mathrm{ac}-$ tivated carbons show L-type isotherms. The Langmuir and Freundlich are the most frequently used models. In this work the Langmuir model was used to describe the relation between the amounts of deltamethrin adsorbed, $\mathrm{C}_{\mathrm{e}} / \mathrm{q}_{\mathrm{e}}$, and the equilibrium concentration $\mathrm{C}_{\mathrm{e}}(\mathrm{mg} / \mathrm{L})$. Langmuir's isotherm model postulates that adsorption occurs on a homogenous surface by monolayer adsorption without interaction between adsorbed molecules, with uniform energies of adsorption on the surface, and no transmigration of adsorbate molecules on the solid surface plane. The linear form of the Langmuir isotherm equation is represented by the following equation [23]:

$$
\frac{C_{e}}{q_{e}}=\frac{1}{b q_{m}}+\frac{C_{\epsilon}}{q_{m}}
$$

where $\mathrm{q}_{\mathrm{e}}$ is the amount adsorbed at equilibrium time $(\mathrm{mg} / \mathrm{g})$, $\mathrm{C}_{\mathrm{e}}$ is the equilibrium concentration of deltamethrin $(\mathrm{mg} / \mathrm{L}), \mathrm{q}_{\mathrm{m}}$ is the maximum adsorption capacity $(\mathrm{mg} / \mathrm{g}$ ), and $\mathrm{b}$ is known as the Langmuir constant $(\mathrm{L} / \mathrm{mg})$ and it is related to the heat of adsorption. The plot of $\mathrm{C}_{\mathrm{e}} / \mathrm{q}_{\mathrm{e}}$ versus $\mathrm{C}_{\mathrm{e}}$ of deltamethrin on activated carbons (CK21, CK11, and CK12) will give a straight line with slope $=1 / \mathrm{q}_{\mathrm{m}}$ and an intercept $=1 / \mathrm{bq}_{\mathrm{m}}$, as shown in Fig. 12. Applying the Langmuir model at two different temperatures, $19^{\circ} \mathrm{C}$ and $35^{\circ} \mathrm{C}$, enables us to calculate the maximum adsorption capacity $(\mathrm{mg} / \mathrm{g})$ and the Langmuir constant $(\mathrm{L} / \mathrm{mg})$ at every temperature with a higher correlation coefficient $\left(\mathrm{R}^{2}\right)$, which ranged between 0.99413 and 0.99948 , indicating a good linear fit for Langmuir's model. From the results shown in Table 5 we can conclude that at constant temperature $\mathrm{q}_{\mathrm{m}}$ increases in the order CK21<CK11 $<\mathrm{CK} 12$ due to the increase in specific surface area and total pore volume (Table 3), which introduces more available pores for adsorption of deltamethrin. Carrying out the adsorption at $35^{\circ} \mathrm{C}$, we observed a significant increase in deltamethrin adsorption, which may be discussed on the basis of the endothermic nature of all the adsorption processes involving intraparticle diffusion, boundary
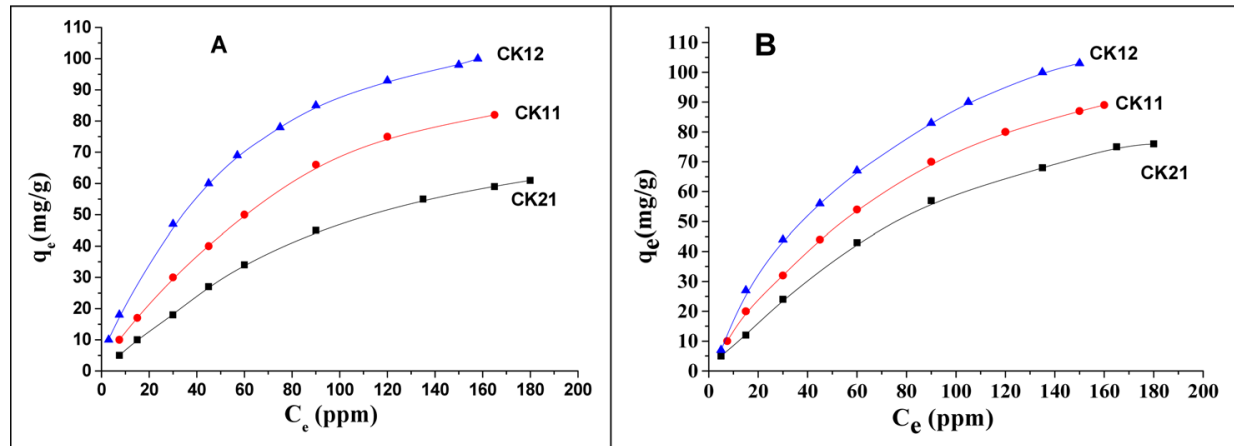

Fig. 11. Adsorption isotherms of deltamethrin for $\mathrm{CK} 21, \mathrm{CK} 11$, and $\mathrm{CK} 12$ at $19^{\circ} \mathrm{C}(\mathrm{A})$ and $35^{\circ} \mathrm{C}(\mathrm{B})$. 

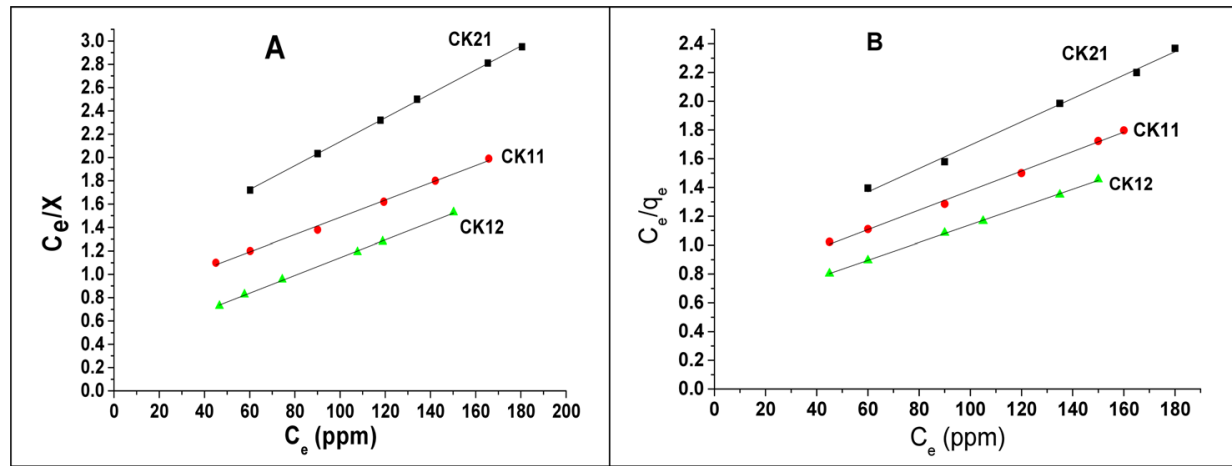

Fig. 12. Linearized form of Langmuir equation for deltamethrin adsorption on $\mathrm{CK} 21, \mathrm{CK} 11$, and $\mathrm{CK} 12$ at $19{ }^{\circ} \mathrm{C}(\mathrm{A})$ and $35^{\circ} \mathrm{C}(\mathrm{B})$.

Table 5. Langmuir isotherm constants for deltamethrin adsorption on CK21, CK11, and CK12 at $19^{\circ} \mathrm{C}$ and $35^{\circ} \mathrm{C}$

\begin{tabular}{ccccccc} 
& \multicolumn{3}{c}{$19^{\circ} \mathrm{C}$} & \multicolumn{3}{c}{$35^{\circ} \mathrm{C}$} \\
\cline { 2 - 7 } Sample & $\mathrm{R}^{2}$ & $\mathrm{q}_{\mathrm{m}}(\mathrm{mg} / \mathrm{g})$ & $\mathrm{b}(\mathrm{L} / \mathrm{mg})$ & $\mathrm{R}^{2}$ & $\mathrm{q}_{\mathrm{m}}(\mathrm{mg} / \mathrm{g})$ & $\mathrm{b}(\mathrm{L} / \mathrm{mg})$ \\
\hline $\mathrm{CK} 21$ & 0.99948 & 97.3 & 0.01927 & 0.99413 & 123 & 0.12449 \\
\hline $\mathrm{CK} 11$ & 0.99605 & 130.2 & 0.02988 & 0.99675 & 147 & 0.24787 \\
\hline CK12 & 0.99909 & 135.9 & 0.12827 & 0.99942 & 162.6 & 0.68617 \\
\hline
\end{tabular}

Table 6. Thermodynamic parameters for deltamethrin adsorption on CK21, CK11, and CK12 at $19^{\circ} \mathrm{C}$ and $35^{\circ} \mathrm{C}$

\begin{tabular}{|c|c|c|c|c|c|c|}
\hline \multirow{2}{*}{ Sample } & \multicolumn{3}{|c|}{$19^{\circ} \mathrm{C}$} & \multicolumn{3}{|c|}{$35^{\circ} \mathrm{C}$} \\
\hline & $\mathrm{K}^{\mathrm{O}}$ & $\Delta \mathrm{G}^{\mathrm{o}}(\mathrm{kJ} / \mathrm{mol})$ & $\Delta \mathrm{S}^{\mathrm{o}}(\mathrm{kJ} / \mathrm{mol} . \mathrm{K})$ & $\mathrm{K}^{\mathrm{O}}$ & $\Delta \mathrm{G}^{\mathrm{o}}(\mathrm{kJ} / \mathrm{mol})$ & $\Delta \mathrm{S}^{\mathrm{o}}(\mathrm{kJ} / \mathrm{mol} . \mathrm{K})$ \\
\hline CK21 & 5.233 & -4.018 & 0.3124 & 5.912 & -4.550 & 0.2979 \\
\hline CK11 & 5.428 & -4.107 & 0.3528 & 6.423 & -4.763 & 0.3366 \\
\hline CK12 & 6.018 & -4.357 & 0.2852 & 6.809 & -4.912 & 0.2722 \\
\hline
\end{tabular}

layer diffusion, and surface adsorption processes. Also, raising the temperature may increase the kinetic energy of deltamethrin molecules and enhance the rate of diffusion of the adsorbate [20].

3.2.4.Thermodynamic parameters of deltamethrin adsorption

Thermodynamic parameters of deltamethrin adsorption on $\mathrm{CK} 21, \mathrm{CK} 11$, and $\mathrm{CK} 12$ were determined at 19 and $35^{\circ} \mathrm{C}$. Thermodynamic parameters (Table 6), namely the thermodynamic equilibrium constant $K_{o}$, Gibbs free energy $\left(\Delta \mathrm{G}^{\circ}\right)$, enthalpy change $\left(\Delta \mathrm{H}^{\circ}\right)$, and entropy change $\left(\Delta \mathrm{S}^{\circ}\right)$, were calculated using the following equations:

$$
\mathrm{K}_{\mathrm{o}}=\mathrm{C}_{\mathrm{s}} / \mathrm{C}_{\mathrm{e}}
$$

where $\mathrm{C}_{\mathrm{s}}$ is the surface concentration of deltamethrin and $\mathrm{C}_{\mathrm{e}}$ the equilibrium concentration.

$$
\Delta \mathrm{G}^{\mathrm{o}}=-\mathrm{RT} \ln \mathrm{K}_{\mathrm{o}}
$$

where $\mathrm{R}$ is the universal gas constant $\left(8.314 \times 10^{-3} \mathrm{~kJ} \cdot \mathrm{K}^{-1} \cdot \mathrm{mol}^{-1}\right)$.

$$
\Delta H^{o}=R\left(\frac{T_{1} T_{2}}{T_{2}-T_{1}}\right) 2.303 \log \frac{b_{2}}{b_{1}}
$$

where $b_{1}$ and $b_{2}$ are the Langmuir constants at 19 and $35^{\circ} \mathrm{C}$, respectively.

$$
\Delta S^{o}=\frac{\Delta H^{o}-\Delta G^{o}}{T}
$$

The values of $\mathrm{K}_{\mathrm{o}}$ increased with an increasing ratio of $\mathrm{KOH}$ : carbon, indicating an increase in the adsorption capacity, which could be related to an increase in the specific surface area and total pore volume of activated carbons. Based on the values of the obtained thermodynamic parameters (Table 6), the negative values of $\Delta \mathrm{G}^{\circ}$ indicate spontaneous adsorption of deltamethrin on the activated carbon samples. Adsorption of deltamethrin can be considered as physisorption when the change in free energy for this process ranges between -4.018 and $-4.912 \mathrm{~kJ}^{-\mathrm{mol}^{-1}}$, because it is known that the absolute magnitude of the change in free energy for physisorption is between -20 and $0 \mathrm{~kJ} \cdot \mathrm{mol}^{-1}$ and that chemisorption occurs between -80 and $-400 \mathrm{~kJ}^{\mathrm{mol}} \mathrm{H}^{-1}$ [24]. It should also be noted that the change in free energy decreases with an increase in temperature, which indicates an increase in adsorption capacity with a rise in temperature. The positive values of entropy change reflect the increased randomness at the solid/solution surface. This is a direct consequence of enhancement of the mobility and extent of penetration within activated carbon pores and overcoming the activation energy bar- 
rier and enhancing the rate of intraparticle diffusion. The positive values of $\Delta \mathrm{H}^{\circ}$ (around $88.3 \mathrm{~kJ} / \mathrm{mol}$ ) confirm the endothermic nature of adsorption and explain the increase in adsorption capacity of the investigated samples to deltamethrin with a temperature increase.

\section{Conclusions}

Potassium hydroxide activated carbons with high adsorption capacity for deltamethrin insecticide were prepared from pistachio nutshells. SEM and nitrogen adsorption at $-196^{\circ} \mathrm{C}$ showed microporosity of activated carbons with a pore radius of around $1.4 \mathrm{~nm}$. FT-IR and $\mathrm{pH}_{\mathrm{pzc}}$ indicated the presence of acidic and basic functional groups. The kinetic studies demonstrated that adsorption of deltamethrin on $\mathrm{KOH}$-activated carbons is a PSO reaction. The adsorption of deltamethrin is very rapid in the initial stage and slowed down while approaching equilibrium, indicating that intraparticle diffusion is not the only rate controlling step in the adsorption process. Thermodynamic studies indicated an endothermic and spontaneous nature for adsorption of deltamethrin on activated carbons.

\section{References}

[1] Corsini E, Liesivuori J, Vergieva T, Van Loveren H, Colosio C. Effects of pesticide exposure on the human immune system. Hum Exp Toxicol, 27, 671 (2008). http://dx.doi.org/10.1177/ 0960327108094509.

[2] Daneshvar N, Aber S, Khani A, Khataee AR. Study of imidaclopride removal from aqueous solution by adsorption onto granular activated carbon using an on-line spectrophotometric analysis system. J Hazard Mater, 144, 47 (2007). http://dx.doi.org/10.1016/j. jhazmat.2006.09.081.

[3] Dich J, Zahm SH, Hanberg A, Adami HO. Pesticides and cancer Cancer Causes Control, 8, 420 (1997).

[4] Ania CO, Béguin F. Mechanism of adsorption and electrosorption of bentazone on activated carbon cloth in aqueous solutions. Water Res, 41, 3372 (2007). http://dx.doi.org/10.1016/j.watres.2007. 03.031.

[5] Hallenbeck WH, Cunningham KM. Pesticides and Human Health, Springer-Verlag, New York (1985).

[6] Youssef AM. Moisture sorption in relation to some characteristics of coal. Carbon, 12, 433 (1974). http://dx.doi.org/10.1016/00086223(74)90009-8.

[7] Youssef AM, El-Shobaky GA, El-Nabarawy T. Adsorption properties of carbons in relation to the various methods of activation. Surf Technol, 7, 451 (1978). http://dx.doi.org/10.1016/0376-4583 (78)90023-7.

[8] Youssef AM, Ahmed AI, El-Bana UA. Adsorption of cationic dye (MB) and anionic dye (AG 25) by physically and chemically activated carbons developed from rice husk. Carbon Lett, 13, 61 (2012). http://dx.doi.org/10.5714/CL.2012.13.2.061.

[9] Guo Y, Yang S, Yu K, Zhao J, Wang Z, Xu H. The preparation and mechanism studies of rice husk based porous carbon. Mater
Chem Phys, 74, 320 (2002). http://dx.doi.org/10.1016/S0254-0584 (01)00473-4.

[10] Yeganeh MM, Kaghazchi T, Soleimani M. Effect of raw materials on properties of activated carbons. Chem Eng Technol, 29, 1247 (2006). http://dx.doi.org/10.1002/ceat.200500298

[11] Özsin G. Production and characterization of activated carbon from pistachio-nut shell [MS Thesis], Middle East Technical University, Ankara, Turkey (2011).

[12] González JF, Román S, Encinar JM, Martínez G. Pyrolysis of various biomass residues and char utilization for the production of activated carbons. J Anal Appl Pyrolysis, 85, 134 (2009). http://dx.doi. org/10.1016/j.jaap.2008.11.035.

[13] Matos J, Nahas C, Rojas L, Rosales M. Synthesis and characterization of activated carbon from sawdust of Algarroba wood. 1. Physical activation and pyrolysis. J Hazard Mater, 196, 360 (2011). http://dx.doi.org/10.1016/j.jhazmat.2011.09.046.

[14] Aguilar C, García R, Soto-Garrido G, Arriagada R. Catalytic wet air oxidation of aqueous ammonia with activated carbon. Appl Catal B, 46, 229 (2003). http://dx.doi.org/10.1016/S09263373(03)00229-7.

[15] Ahmad AL, Loh MM, Aziz JA. Preparation and characterization of activated carbon from oil palm wood and its evaluation on Methylene blue adsorption. Dyes Pigments, 75, 263 (2007). http://dx.doi. org/10.1016/j.dyepig.2006.05.034.

[16] Liu QS, Zheng T, Wang P, Guo L. Preparation and characterization of activated carbon from bamboo by microwave-induced phosphoric acid activation. Ind Crops Prod, 31, 233 (2010). ttp://dx.doi org/10.1016/j.indcrop.2009.10.011.

[17] Yang T, Lua AC. Characteristics of activated carbons prepared from pistachio-nut shells by physical activation. J Colloid Interface Sci, 267, 408 (2003). http://dx.doi.org/10.1016/S0021-9797(03)00689-1.

[18] Boehm HP. Surface oxides on carbon and their analysis: a critical assessment. Carbon, 40, 145 (2002). http://dx.doi.org/10.1016/ S0008-6223(01)00165-8.

[19] Jankowska H, Świątkowski A, Choma J, Kemp TJ. Active Carbon, E. Horwood, New York (1991).

[20] Aravindhan R, Fathima NN, Rao JR, Nair BU. Equilibrium and thermodynamic studies on the removal of basic black dye using calcium alginate beads. Colloids Surf A, 299, 232 (2007). http:// dx.doi.org/10.1016/j.colsurfa.2006.11.045.

[21] Weber W, Morris J. Kinetics of adsorption on carbon from solution. J Sanit Eng Div Am Soc Civ Eng, 89, 31 (1963).

[22] Malik PK. Use of activated carbons prepared from sawdust and rice-husk for adsorption of acid dyes: a case study of Acid Yellow 36. Dyes Pigments, 56, 239 (2003). http://dx.doi.org/10.1016/ S0143-7208(02)00159-6.

[23] Langmuir I. The adsorption of gases on plane surfaces of glass, mica and platinum. J Am Chem Soc, 40, 1361 (1918). http://dx.doi. org/10.1021/ja02242a004.

[24] Yu Y, Zhuang YY, Wang ZH. Adsorption of water-soluble dye onto functionalized resin. J Colloid Interface Sci, 242, 288 (2001) http://dx.doi.org/10.1006/jcis.2001.7780. 